\title{
鉄道沿線斜面の降雨時リスク評価に基づく 防災対策の意思決定方法
}

\author{
布川 修 1 -杉山 友康 2 - 森 泰樹 3 - 畑 明仁 4 \\ 1正会員 （財)鉄道総合技術研究所 防災技術研究部（干185-8540 東京都国分寺市光町二丁目8-38） \\ E-mail: onunokaw@rtri.or.jp \\ 2フェロー （財) 鉄道総合技術研究所防災技術研究部（干185-8540 東京都国分寺市光町二丁目 8-38） \\ E-mail: sugiyama@rtri.or.jp \\ 3正会員 西日本旅客鉄道（株）構造技術室（干532-0011大阪府大阪市淀川区西中島五丁目4-20-2F） \\ E-mail: taiki-mori@westjr.co.jp \\ 4正会員 大成建設 (株) 土木技術研究所（†245-0051 神奈川県横浜市戸塚区名瀬町344-1) \\ E-mail: hata@ce.taisei.co.jp
}

\begin{abstract}
鉄道沿線に数多く存在する斜面を対象として，降雨時に発生する土砂災害を防止する対策を効果的に実 施するためには, 各斜面の耐雨性のみならず災害発生時の営業損失や復旧費なども考慮して, 各斜面の災 害に対する危険度を定量的に評価し，この結果を用いて防災対策の優先順位や方法を決定するのが望まし い. そこで, 本研究では, 鉄道沿線斜面において降雨時に発生が懸念される土砂災害やそれが鉄道運行に 与える影響をリスクとして定量的に評価する方法について論じた．具体的には，鉄道で実施されている運 転規制を考慮して斜面の崩壊発生確率分布や年間降雨頻度期待值分布を作成し，これらをもとにリスクを 算出する方法を提案した。さらに，リスク算出結果を利用した防災対策の意思決定方法を計算事例により 示した.
\end{abstract}

Key Words : slope failure, rainfall, rail road, disaster risk, risk estimation method

\section{1. まえがき}

降雨により発生する土砂災害（盛土崩壊や切土崩壊な ど）から列車の安全を確保するためには，災害が発生す る恐れのあるすべての斜面にのり面防護工などのハード 対策を実施し，斜面の降雨に対する耐力（以下，耐雨性 という）を向上させることが理想である．しかし，沿線 に数多くの斜面が存在し，ハード対策を実施するための 年間予算も限られていることなどの理由により，鉄道で はハード対策とある雨量值を超えたときに列車の運行を 規制するなどのソフト対策とを組み合わせて実施するこ とで列車の安全を確保している.

土砂災害に対する対策を効果的に実施するためには, 定期的な検査等により判断される各斜面の健全度のみな らず，災害が発生した場合に想定される営業損失や復旧 費なども考慮して斜面の崩壊危険度を定量的に評価し， この評価結果をもとに対策の優先順位や方法を決定する のが望ましい. しかしながら，こうした評価手法が確立 されていないため, 斜面の健全度, 斜面が位置する線区
の重要度，営業利益などから経験的に防災対策の意思を 決定しているのが現状である。

本論文は，鉄道沿線斜面において降雨時に発生が懸念 される土砂災害やそれが鉄道運行に与える影響をリスク として定量的に評価する方法について論じたものである. 具体的には，鉄道で実施されている運転規制を考慮して 斜面の崩壊発生確率分布や年間降雨頻度期待值分布を作 成し，これらをもとにリスクを算出する方法を提案し， リスク算出結果を利用した防災対策の意思決定方法を計 算事例により示した.

\section{2. 斜面災害に対するリスク評価に関する過去の 研究}

近年自然災害に対する危険度を単に構造物の耐力で評 価するのみならず，被害を受けた場合の損失を考慮して 危険度を評価することの重要性が指摘されている. その ため, 崩壊を発生させる誘因である降雨と素因である斜 
面の耐雨性を考慮して，斜面がある期間内に崩壊（破 壊）する可能性を確率的に求め, この結果と被害を受け た場合の損失から斜面の崩壊危険度をリスクとして評価 する研究がなされている.

例えば，大津ら ${ }^{11}$ は，高速道路沿線の斜面を対象とし て，イベントツリーにより斜面崩壊時の被害を場合分け し，それぞれの発生確率と損失からリスクを求める方法 を提案している. なお，斜面の降雨時リスクを算出する ために，榎)が提案している表層すべりの性能関数およ び三連一次タンクモデルを利用して斜面が破壊する確率 を求め，これと想定降雨レベルが1年間に発生する確率 から，斜面の年間破壊確率を算出する方法を提案してい る3．また，沖村ら出は，道路のり面を対象として，崩壊 メカニズムを踏まえて破壊確率と損失を求め，リスクを 算出する方法を提案している。ここでは，沖村5が提案 している多平面安定解析および沖村, 市川向が提案して いる集水モデルを利用して斜面が破壊する確率を求め, これと年最大時間雨量の超過確率をもとに設定した入力 降雨条件から, 斜面の年間破壊確率を算出している4 また，田中らわは，道路斜面を対象として，道路防災点 検の結果と崩壊の履歴を用いて実施した統計解析結果と 降雨の年超過確率から, リスクを算出する方法を提案し ている.

これらの研究結果は, 各斜面の災害に対する危険度を リスクとして評価することで，合理的に防災投資の優先 順位を判断することが可能であることを示唆している.

一方，リスクを算出する方法，特に，斜面の耐雨性の 算出方法が各研究で異なり，斜面安定の理論に基づく方 法と統計解析の結果に基づく方法に大きく分けられる.

斜面安定の理論に基づいて斜面の耐雨性を算出する方法 は様々な斜面に適用可能であり, 統計解析の結果に基づ く方法と比較して精度が高いが，崩壊の危険性が高い斜 面が沿線に多数存在する場合は作業量が膨大になること が想定される.また，統計解析の結果に基づいて斜面の 耐雨性を算出する方法は, 解析に用いたデータにより適 用範囲が限定され，斜面安定の理論に基づく方法よりも 精度が低いが，崩壊の危険性が高い斜面が沿線に多数存 在しても比較的作業量が少なく, 実務上有用であること が想定される.

前述したとおり，鉄道では沿線に崩壊の危険性が高い 斜面が多数存在することから，のり面防護工などのハー ド対策とある雨量值を超えたときに列車の運行を規制す るなどのソフト対策とを組み合わせて実施することで列 車の安全を確保している.このため, 筆者らは, 鉄道沿 線で発生した崩壊事例データを用いた統計解析の結果を もとに斜面の耐雨性を算出する岡田 $5^{8), 99}$ ，杉山ら ${ }^{10), 11)}$ の手法を利用して，鉄道の降雨時運転規制を考慮して斜 面崩壊の発生頻度期待值を算出する方法を提案した ${ }^{12)}$.
本研究では，この方法をもとに斜面の降雨時リスクを算 出する方法について論じた.

\section{3. 研究内容}

鉄道ではある雨量值を超えたときに列車の運行を規制 する運転規制が実施されている. 図-1に運転規制におけ る雨量指標と規制值との関係の例を示す。在来線では一 般的に，12時間以上降雨が中断しない場合における降り 始めからその時刻までの降雨量の累積值を連続雨量 $R$ と 定義し，現時刻におけるこの值と時間雨量 $r$ が図-1に示 す階段状の規制值の線を越えた場合に列車の運行を規制 している ${ }^{13)}$. 規制方法として, 列車を徐行させる場合と 運転を中止させる場合とがあるが，論旨を簡潔にするた め, 本研究では列車を中止させる規制のみを対象とした.

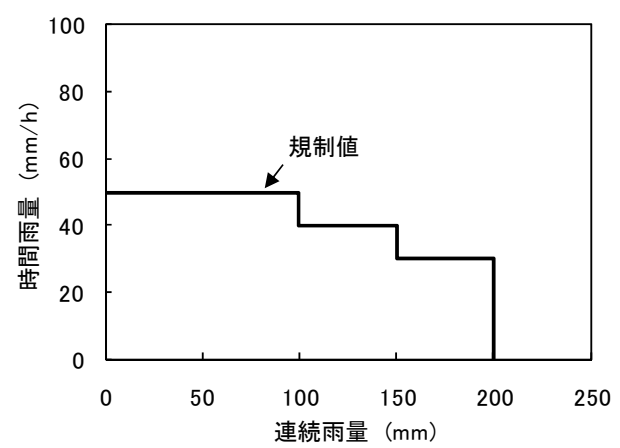

図-1＼cjkstart運転規制の例

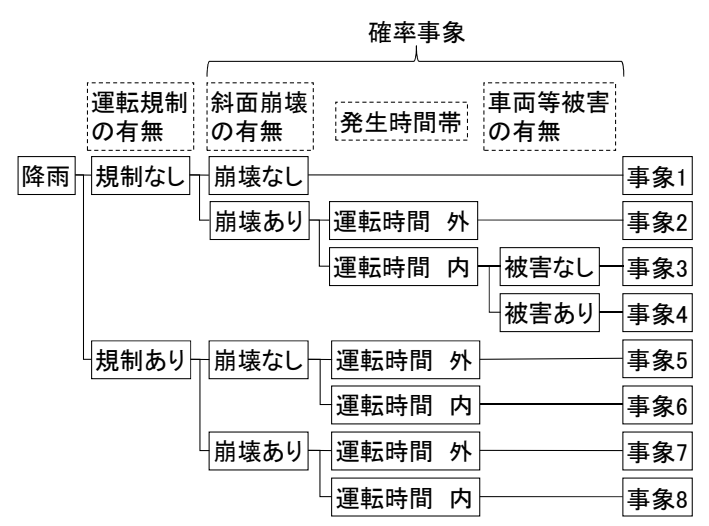

図-2 降雨時に想定される事象

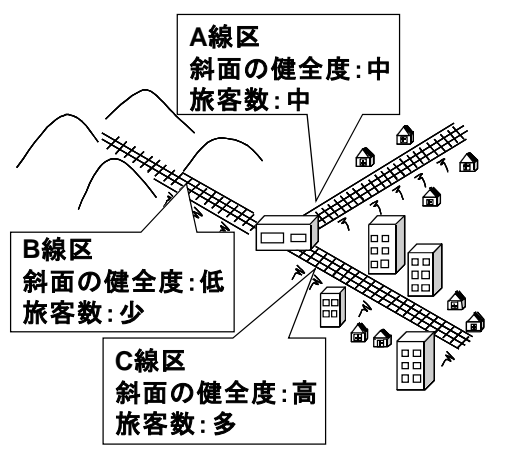

図-3３線区に斜面が存在する場合の例 


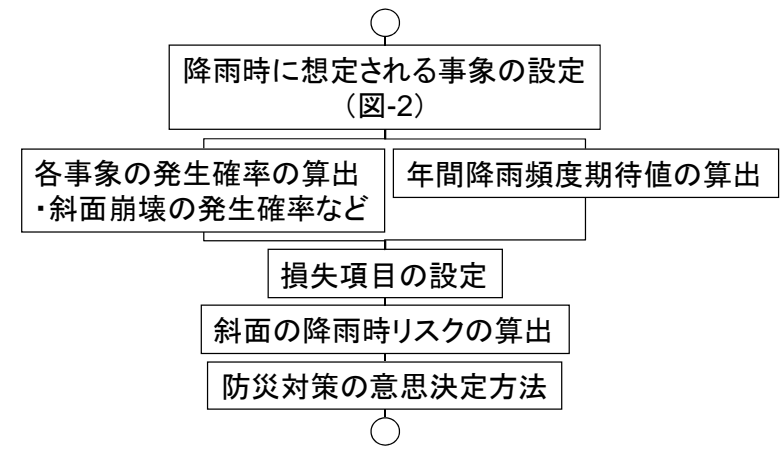

図-4 本研究の流れ

ここで，降雨時に列車の運転が規制されていないとき に斜面が崩壊した場合，崩壊土砂に列車が乗り上げるな どの被害が発生する可能性が高まるが，列車の運転が規 制されている場合は，崩壊の応急・復旧費のみが被害と して発生することが想定される．このように，列車の運 転を規制しているかどうかにより発生する被害が異なる ことから，これを考慮して鉄道沿線斜面の降雨時リスク を算出するために，降雨時に想定される事象を図-2に示 すとおりイベントツリー形式で設定する.

具体的には，ある規模の降雨が発生した場合を，まず， 降雨量と降雨時運転規制の規制值との比較により, 運転 規制の有無を判別する.さうに，斜面崩壊の有無と発生 時間帯（運転時間の内外）により場合分けし，運転時間 内に列車運行が規制されずに斜面が崩壊した場合につい ては，さらに車両等被害の有無により場合分けした。 な お，鉄道沿線の斜面には崩壊を検知寸る装置が設置され ている場合があり，こうした装置を設置している斜面や 斜面が位置する箇所をとおる列車の速度が遅く，かつ列 車からの見通しがよい場所では，斜面が崩壊しても崩壞 箇所の手前で列車が停止することが可能であり，車両等 に被害が発生する恐れが低くなる。これとは逆の場合は, 斜面崩壊箇所に列車が進入することにより，車両等に被 害が発生する可能性が高くなる.

したがって, 降雨時に想定される事象として8パター ンを設定した.この8パターンのうち, 事象5は列車の運 転時間外に規制を必要とする降雨が発生した場合であり, 規制ありに場合分けされるが実際には規制を行わないこ とになる. なお，上記の場合分けのうち，斜面崩壊の有 無, 運転時間帯, 車両等被害の有無は確率的な事象であ る.

図-3に示すように，旅客数が異なるA，B，Cの3線区 に斜面が存在する場合，例えば，「斜面の健全度」と 「旅客数」が個別に定量化されていても，これらを総合 して斜面の崩壊危険度を評価する指標がなければ，防災 対策の順位や方法を定量的に決定することは困難である. 本研究では, 降雨の地域特性, 運転規制值, 斜面の而雨 性, 路線の営業利益や崩壊規模から想定される崩壊発生
時の損失等を考慮して斜面の降雨時リスクを算出し， 様々な地域に存在する路線沿線の斜面を対象として, 防 災対策の優先順位等を意思決定する方法を提案すること を目的とする。

そこで，信頼性解析手法 ${ }^{14}$ に準拠し，斜面の降雨時リ スクを式(1)により求める方法について検討する.

$$
\begin{gathered}
R_{\text {isk }}=\Sigma\left(P_{i} \times C_{i}\right) \quad(i=1 \sim 8) \\
P_{i}=p_{i} \times n_{i}
\end{gathered}
$$

ここで,

$R_{\mathrm{ikk}}$ : 斜面の降雨時リスク (円/年)

$P_{i}$ : 降雨時に想定される事象iの年間発生頻度期待値 (回/年)

$C_{i}:$ 降雨時に想定される事象iが生じた時の損失（円/ 回)

$p_{i}:$ 降雨時に想定される事象 $\mathrm{i}$ の発生確率

$n_{i}$ : 降雨時に想定される事象 $\mathrm{i}$ 年間降雨頻度期待值 (回/年)

すなわち, 斜面の降雨時リスクを降雨により想定され る年間あたりの損失期待值と定義する. そして，降雨時 に想定される各事象の発生確率と年間降雨頻度期待值を 乗じることで各事象の年間発生頻度期待值を求める.さ らに，これと損失とを乗じることで各事象のリスクを求 め，これらを足し合わせることで斜面の降雨時リスクが 算出できる. なお, 本研究では, 鉄道事業者が主に管理 している盛土と切土を対象とし，以下，これらを総括し て斜面という.

本研究の流れを図-4に示す，この図に示すとおり，運 転規制で用いられている雨量指標（時間雨量 $r$ と連続雨 量R）を考慮して, 各事象の発生確率と年間降雨頻度期 待值を算出する方法 ${ }^{12}$ をまず示す. そして, 損失項目を 設定し，これらをもとにリスクを算出する方法とリスク 算出結果を利用した防災対策の意思決定方法を示寸。

\section{4. 各事象の発生確率の算出}

\section{（1） 発生確率の算出方法}

図-2に示したイベントツリーより, 時間雨量 $r$, 連続 雨量Rの降雨時において想定される事象は，運転規制の 有無によりまず判別される. 運転規制の有無ごとに, 各 事象の発生確率は, 以下の式により求められる.

$$
p_{i}=p_{a i} \times p_{b i} \times p_{a}
$$

ここで, $p_{i}$ : 各事象の発生確率

$$
\begin{aligned}
& p_{a i}: \text { 斜面崩壊の有無別発生確率 } \\
& p_{b i}: \text { 運転時間内外別確率 } \\
& p_{a i}: \text { 車両等被害の有無別発生確率 }
\end{aligned}
$$

なお，例えば，斜面崩壊の有無別発生確率は，斜面崩 
壊の発生確率を $F_{i}$ とすると, 斜面崩壊ありの場合 $P_{a i}=F_{i}$, 斜面崩壊なしの場合 $P_{a i}=\left(1-F_{i}\right)$ となる.この章では, 上記で示した斜面崩壊の発生確率算出方法を中心に述心 る.

\section{（2）限界雨量に基づく斜面の危険度評価手法}

降雨による斜面崩壊の発生確率を求めるためには, 対 象斜面がどの程度の降雨量で崩壊するか，すなわち耐雨 性を評価する必要がある. 本研究では, 而打雨性の評価手 法として，岡田ら ${ }^{8,99}$, 杉山ら ${ }^{10,11}$ が開発した限界雨量に 基づく斜面の危険度評価手法を用いる．この手法は，簡 易な調査により得られる盛土や切土の各種条件から崩壞 の可能性が高まる雨量（限界雨量と定義している）を算 出し, この雨量を鉄道で実施されている降雨時運転規制 の雨量指標上に表すものである.

岡田ら，杉山らが提案した而雨性の評価手法は，鉄道 沿線で発生した盛土や切土の崩壊事例データを統計解析 することで作成されたものである.このため，前述した

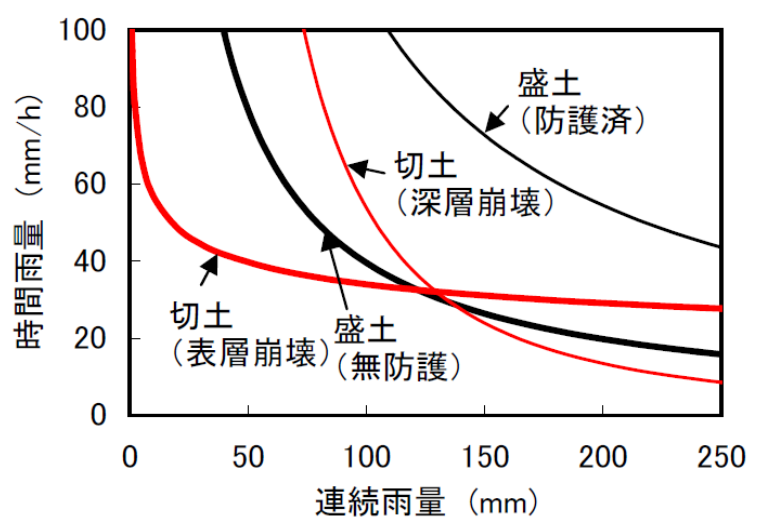

図-5 限界雨量曲線の例
とおり，斜面安定の理論に基づく而雨性の評価方法と比 較して精度が劣ることが想定される．また，崩壊事例デ 一夕の統計解析であるため, 崩壊の危険性が高いと判断 される斜面にしか適用できないという久点がある。しか し，鉄道の降雨時運転規制の雨量指標上に而讨雨性が表現 されるため耐雨性と運転規制值との比較が容易であるこ と，斜面安定の理論を用いた評価手法と比較して簡易な 調査結果を用いて而雨性を評価することが可能なこと， などからこの手法を用いて耐雨性を評価する.

鉄道の降雨時運転規制の雨量指標上に限界雨量を表し た例を図一に示す，図に示すとおり，後述する盛土・切 土（崩壊の形状を表層崩壊と深層崩壊に区別している） ごとに設定された評価基準を用いて算出される限界雨量 $L$ は, 以下の式により連続雨量 $R$ と時間雨量 $r$ 軸とした 平面上に曲線（以下，限界雨量曲線という）で表される.

$$
L=R^{m} \cdot r^{n}
$$

ここで, $m, n:$ 定数

定数 $m, n$ は, 盛土の場合 $m=0.3, n=0.3^{8)}$, 切土 (表層 崩壊）の場合 $m=0.2, n=0.9^{9}$ ), 切土 (深層崩壊) の場合 $m=0.4, n=0.2^{10)}$, である.

表-1に例として盛土の限界雨量を算出寸る評価基準を 示寸.この評価基準は, 崩壊事例データを用いて, 盛土 が崩壊したときの実降雨（連続雨量 $R$ と時間雨量 $r$ ）を 式(4)に代入することで求まる限界雨量を目的変数とし, 盛土の条件を説明変数として実施した数量化類解析の 結果から作成されている. 評価基準には基本点と盛土条 件ごとの評価点が定められており, 評価対象の条件から これらを求めて加算することで限界雨量を算出寸る.

限界雨量が大きいほど斜面の耐雨性が高く, 図-5の右 上に限界雨量曲線が表される. また, 斜面に張ブロック

表-1 盛土の評価基準（文献 8)を一部修正・加筆）

\begin{tabular}{|c|c|c|c|c|c|}
\hline \multicolumn{2}{|c|}{ 基本点 } & \multicolumn{4}{|c|}{13.14} \\
\hline & 条件 & \multicolumn{4}{|c|}{ 条件（上段）と評価点（下段） } \\
\hline \multirow[t]{4}{*}{$\begin{array}{l}\text { 盛土の } \\
\text { 構造条件 }\end{array}$} & \begin{tabular}{|l} 
盛土高さ \\
$H \quad(\mathrm{~m})$
\end{tabular} & \multicolumn{4}{|c|}{$P=-3.18 \times 10^{-3} H^{2}-7.09 \times 10^{-2} H+7.87 \times 10^{-1}$} \\
\hline & \multirow[t]{2}{*}{ 土質 $S_{E}$} & 粘性土 & 砂質土 & 磻質土 & \\
\hline & & -1.05 & 0.07 & 0.14 & \\
\hline & $\begin{array}{l}\text { 貫入強度 } \\
N_{C}\end{array}$ & \multicolumn{4}{|c|}{$P=-9.79 \times 10^{-3} N_{C}^{2}+4.75 \times 10^{-1} N_{C}-2.24$} \\
\hline \multirow[t]{4}{*}{ 基盤条件 } & \multirow{2}{*}{$\begin{array}{l}\text { 表層地盤の地 } \\
\text { 質 } S_{B}\end{array}$} & \multicolumn{2}{|c|}{ 沖積地盤 } & \multicolumn{2}{|c|}{ その他 } \\
\hline & & \multicolumn{2}{|c|}{-0.38} & \multicolumn{2}{|c|}{0.22} \\
\hline & \multirow{2}{*}{$\begin{array}{l}\text { 地盤の傾 斜角 } \\
\theta_{B}\end{array}$} & \multicolumn{2}{|c|}{ 平坦 } & \multicolumn{2}{|c|}{10 度以上 } \\
\hline & & \multicolumn{2}{|c|}{1.34} & \multicolumn{2}{|c|}{-1.10} \\
\hline \multirow{8}{*}{$\begin{array}{l}\text { 集水· } \\
\text { 浸透条件 }\end{array}$} & \multirow{2}{*}{$\begin{array}{l}\text { 透水係数 } \\
k \quad(\mathrm{~cm} / \mathrm{s})\end{array}$} & $k<10^{-4}$ & $10^{-4} \leqq k<10^{-3}$ & $10^{-3} \leqq k<10^{-2}$ & $10^{-2} \leqq k$ \\
\hline & & -0.17 & 0.26 & -0.41 & 0.86 \\
\hline & \multirow{2}{*}{$\begin{array}{l}\text { 集水地形 } \\
W_{G}\end{array}$} & 無し & 対象側 & 反対側 & \\
\hline & & 0.52 & -3.23 & -1.83 & \\
\hline & \multirow{2}{*}{$\begin{array}{l}\text { 縦断形態 } \\
T_{L}\end{array}$} & \multicolumn{2}{|c|}{ 切盛境界・落込勾配 } & \multicolumn{2}{|c|}{ 平坦 $\cdot$ 単勾配 } \\
\hline & & \multicolumn{2}{|c|}{-0.53} & \multicolumn{2}{|c|}{-0.30} \\
\hline & \multirow{2}{*}{$\begin{array}{l}\text { 横断形態 } \\
T_{H}\end{array}$} & \multicolumn{2}{|c|}{ 純盛 } & \multicolumn{2}{|c|}{ 片切片盛・腹付 } \\
\hline & & \multicolumn{2}{|c|}{0.21} & \multicolumn{2}{|c|}{-0.16} \\
\hline $\begin{array}{l}\text { 経 験 雨 量 } \\
\text { 条件 }\end{array}$ & $\begin{array}{l}\text { 経験雨量 } \\
R_{E}(\mathrm{~mm})\end{array}$ & \multicolumn{4}{|c|}{$P=-1.06 \times 10^{-10} R_{E}{ }^{2}+5.50 \times 10^{-5} R_{E}-2.96$} \\
\hline \multirow{3}{*}{\multicolumn{2}{|c|}{$\begin{array}{l}\text { 防護工 } \\
\text { (効果率 } 100 \% \text { の場合) }\end{array}$}} & \multicolumn{2}{|c|}{ 防護工種類 } & & \\
\hline & & プレ & 卜格子枠 & & \\
\hline & & & ック & & \\
\hline
\end{tabular}


等の防護工が施工された場合には，表-1に示したとおり， 防護工の効果点が現状の限界雨量に加算されるため, 耐 雨性が向上するものとして評価される ${ }^{11}$.

\section{（3）斜面崩壊の発生確率}

前節で説明したとおり，本研究で耐雨性を評価するた めに利用する限界雨量に基づく斜面の危険度評価手法は, 過去の崩壊事例データを用いた統計解析の結果をもとに 作成されている．したがって，崩壊事例データを用いて， 実際の崩壊時の降雨（連続雨量 $R$ と時間雨量 $r$ ）を式(4)に 代入することで求まる限界雨量 $L_{a}$ と, 斜面条件から表 -1 に示した評価基準により求まる限界雨量 $L_{b}$ との值には残 差が生じる. データ数が多い統計解析の場合, $L_{a}$ と $L_{b}$ の 残差は一般的に平均 0 , 標潐偏差 $\sigma$ の正規分布に従う.

ここで，限界雨量に基づく斜面の危険度評価手法を， この手法作成時に使用していない全く別の盛土や切土, すなわち崩壊の恐れが高い盛土や切土に適用する場合を 考える.この場合において表-1に示した評価基準により

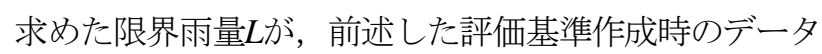
で求めた $L_{a}$ と $L_{b}$ の残差と同じばらつきを持つと仮定する と, 図-6 $6^{12)}$ に示寸ように限界雨量に忍じた崩壊発生確率 が得られる. 図-6から, 崩壊発生確率ごとの限界雨量曲 線を表すと図- $7^{12)}$ に，この図を三次元的に表すと図-8 $8^{12)}$ のような崩壊発生確率分布が得られる.

図-8を用いることで, 連続雨量 $R$, 時間雨量 $r$ 応じた 崩壊発生確率Fを算出することができる.

\section{（4）その他の発生確率}

運転規制の有無は，図-1で示したように，連続雨量と 時間雨量を軸とする平面上において定められている階段 状の規制值から連続雨量 $R$, 時間雨量 $r$ に応じて判別で きる.

運転時間内外別確率は，対象とする斜面を通過する始 発列車から最終列車までの時間を算出し，1日における その割合を求めることで算出することができる.

車両被害の有無別発生確率は, 斜面崩壊の形状や規模, 線路脇の対策工の有無, 線路の線形（直線あるいはカー ブ区間）などにより決定されると考えられる，なお，斜 面崩壊の形状や規模を予測15)寸れば，この発生確率を求 める際の参考となる.

\section{5. 年間降雨頻度期待値の算出}

ここでは，運転規制で用いられている雨量指標を考慮 して, 連続雨量 $R$ と時間雨量 $r$ 軸とした年間降雨頻度期 待值の分布を作成することで年間降雨頻度期待值を算出 する方法を述べる.

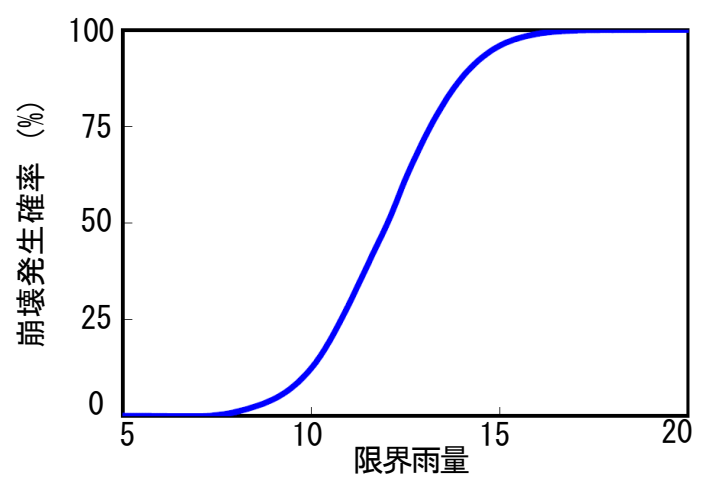

図-6 限界雨量と崩壊発生確率との関係 ${ }^{12)}$ (盛土, $L=12$ の場合)

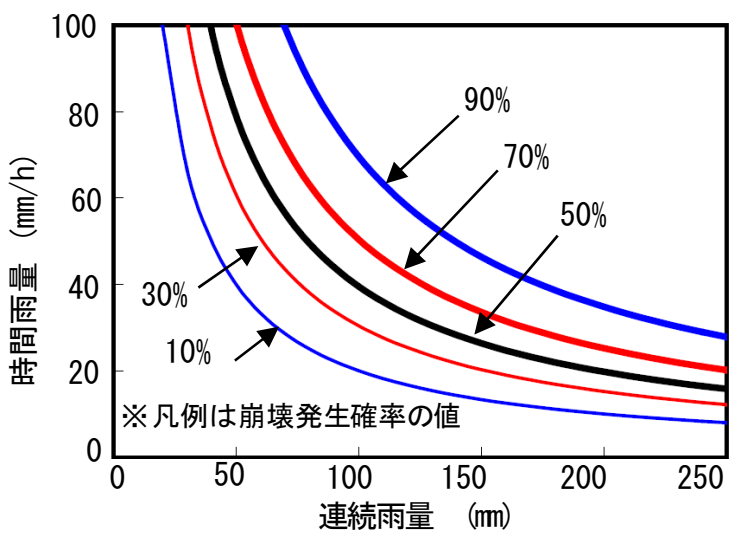

図-7＼cjkstart崩壊発生確率ごとの限界雨量曲線 ${ }^{12)}$ (盛土， $L=12$ の場合)

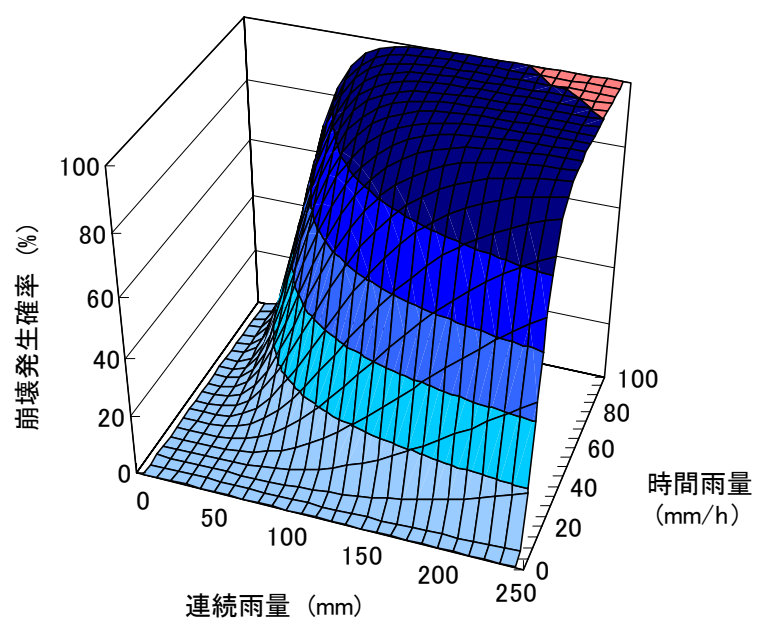

図-8 崩壊発生確率分布（盛土， $L=12$ の場合） ${ }^{12)}$

降雨頻度を求めるためには，連続する降雨を1降雨と し，1降雨の代表值を定義する必要がある．本研究では， 降り始めから連続雨量が 0 となるまでを1降雨とし，1降 雨において式(4)と同じ式を用いて求まる降雨指数S（= $R^{m} r n, m, n$ は係数）が最大となるときの連続雨量 $R$ と時 間雨量rを1降雨の代表値とした。

対象斜面近傍の年間降雨頻度期待值分布の作成方法は 次のとおりである.1)対象斜面近傍のアメダス観測所デ 
一夕等の降雨履歴を分析し, 年間降雨頻度分布を作成す る. 2)上記1)で得られた降雨頻度分布を時間雨量 $1 \mathrm{~mm} / \mathrm{h}$ ごとに区分し，それぞれの区分で連続雨量の小さい方に 累積させた頻度分布（以下，条件付き累積降雨頻度分布 という）を作成する，3)上記2)で得られた条件付き累積 降雨頻度分布を3次元の関数式で近似する. 4)上記3)で作 成される近似した条件付き累積降雨頻度分布から年間降 雨頻度期待值分布を作成する.

例として，アメダス観測所「東京」のデータ（1976年 〜2007年の32年間）を用い，降雨指数Sを盛土の場合の 定数 $(m=n=0.3)$ により求めることで年間降雨頻度期待 值分布を作成する．上記1)により作成した年間降雨頻度 分布を図-912)に示す.なお，この図では時間雨量 $20 \mathrm{~mm}$ 以下，連続雨量 $50 \mathrm{~mm}$ 以下，年間降雨頻度0.2回以下の範 囲を示した．上記2)で条件付き累積降雨頻度分布を作成 し，上記3)でこれを関数式で近似した理由は，図-9に示 したように年間降雨頻度分布が，降雨量の多い領域にお いて頻度のばらつきが大きく，これを直接近似すると精 度が低くなったためである。

条件付き累積頻度分布を近似する関数式としては，3 つの近似関数型について近似精度を検証した結果，以下 に示す対数正規型の関数式を用いる. この関数式は，既 存の2次元確率分布から基準化条件等を除外した関数型 を参考にして設定している.

$$
\begin{aligned}
f_{1}(r, R) & =\frac{A}{2 \pi a b \sqrt{1-c^{2}} r R} \exp \left[\frac { - 1 } { 2 ( 1 - c ^ { 2 } ) } \left\{\left(\frac{\ln r-d}{a}\right)^{2}\right.\right. \\
& \left.\left.-2 c\left(\frac{\ln r-d}{a}\right)\left(\frac{\ln R-e}{b}\right)+\left(\frac{\ln R-e}{b}\right)^{2}\right\}\right]
\end{aligned}
$$

ここで, $A, a, b, c, d, e:$ 係数

図-9から作成した条件付き累積降雨頻度分布とこの分 布を式(5)で示した関数型で近似した結果を図-1012)に, この結果から作成した年間降雨頻度期待值の分布を図$11^{12)}$ に示す。年間降雨頻度分布（図-9, ここでは近似前 という）とこれをもとに作成した年間降雨頻度期待值分 布（図-11，ここでは近似後という）を時間雨量，連続 雨量とも1mmの単位で離散化し, 離散化した時間雨量, 連続雨量に対応するそれぞれの年間降雨頻度について, 近似前と近似後の差を求めて相関係数を算出すると 0.96 であった。また，離散化した時間雨量，連続雨量に対応 するそれぞれの年間降雨頻度を近似前と近似後ごとにす べて足しあわせることで求められる総頻度は，近似前が 76.7 (回/年)，近似後が70.0（回/年）であった.

図-11を用いることで, 連続雨量 $R$, 時間雨量 $r$ こ応じ た年間降雨頻度期待值を算出することができる.

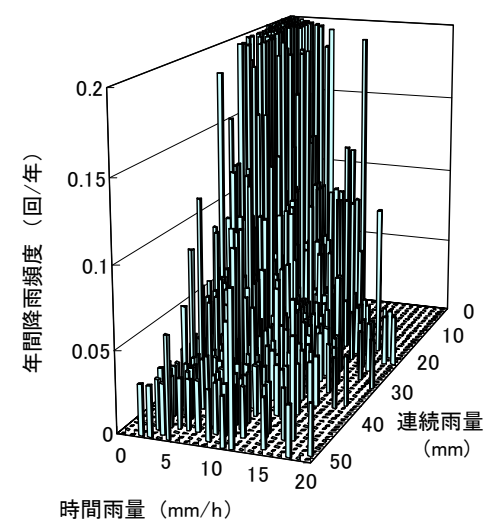

図-9 降雨頻度分布 ${ }^{12)}$ (アメダス観測所「東京」)

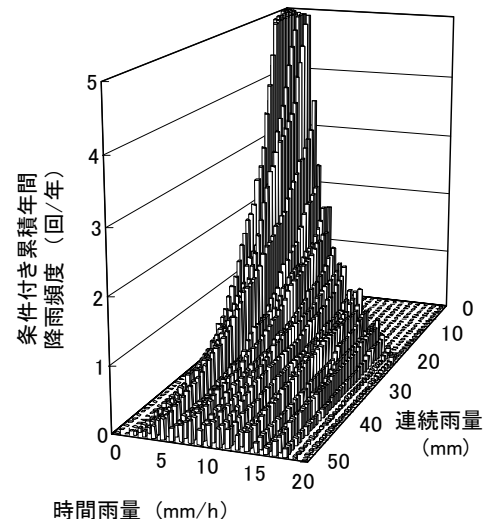

(a) 近似前

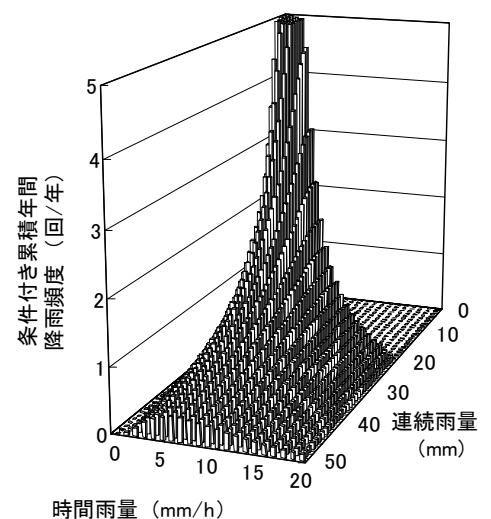

(b) 近似後

図-10 条件付き累積降雨頻度分布の近似結果 ${ }^{12)}$ （アメダス観測所「東京」）

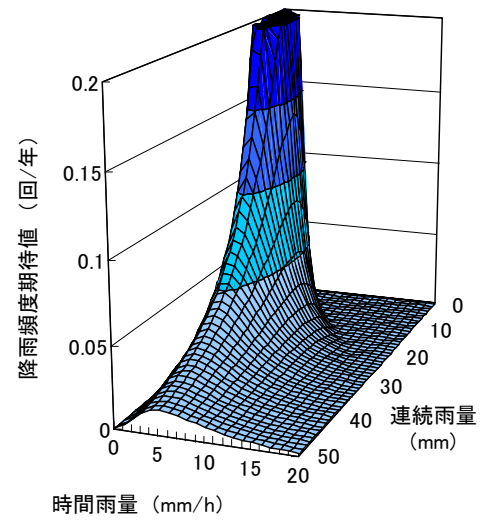

図-11 年間降雨頻度期待值分布 ${ }^{12)}$ （アメダス観測所「東京」） 


\section{6. リスクの算出方法}

\section{(1) 損失項目の設定}

降雨時に想定される事象が生じたときの損失を算出す るためには，損失項目を決定する必要がある。これらは， 対象とする箇所により異なることが想定される。このた め，実際に本研究を適用する場合には，線路の見通し距 離, 列車速度, 一列車あたりの乗車人員等の線区の特性 を考慮して，斜面ごとに損失項目を設定することとなる

ここでは，一例として，損失項目を1)車両等被害額， 2)斜面崩壊時の応急費（必要により列車を運行させるた めに必要な線路および電気設備の復旧費用を含む），3） 斜面崩壊時の復旧費，4)営業損失，の4項目とし，降雨 時に想定される各事象に該当する損失項目を表-2に示し た. なお，営業損失は，斜面崩壊が発生した場合と斜面 は崩壊していないが列車の運行を規制した場合とでは費 用が異なる。

上記で示した損失項目のうち，斜面崩壊時の応急費， 復旧費，営業損失費については崩壊の規模によって異な り，筆者らが既に提案した崩壊規模の予測手法 ${ }^{15}$ を用い て，規模に応じた被害額を設定する.

\section{(2) リスクの算出}

3章〜5章で検討した内容を踏まえて，リスク計算の手
順を降雨時に想定される各事象の頻度期待值と損失の算 出に分けて整理した結果を図-12示す. リスクを計算す るために必要な条件項目は，降雨条件，斜面条件，運転 規制の規制值，列車運行時間帯，営業利益，線区の特性 条件（線路の見通し距離，列車速度等）である. これら から年間降雨頻度期待值分布，崩壊発生確率分布を作成 することで各事象の発生頻度期待值を算出する。さらに, 上記条件項目から斜面崩壊時の応急費，復旧費，営業損 失などを設定することで各事象の損失を算出する.

対象とする斜面の降雨時リスクを式(1), 式(2)に沿つ て計算するために必要な算出項目を整理した結果を図一 13に示す.この図に示すとおり，降雨時に想定される各 事象の発生頻度期待值と損失とから斜面の降雨時リスク が計算できる.

表-2＼cjkstart事象ごとに該当する損失項目

\begin{tabular}{|c|c|c|c|c|c|}
\hline \multirow[b]{2}{*}{ 事象No. } & \multicolumn{4}{|c|}{ 損失項目 } & \multirow{2}{*}{$\begin{array}{c}\text { 損失 } \\
\text { (円/回) } \\
\text { (合計) }\end{array}$} \\
\hline & $\begin{array}{l}\text { 車両等 } \\
\text { 被害額 }\end{array}$ & 応急費 & 復旧費 & $\begin{array}{l}\text { 営業 } \\
\text { 損失 }\end{array}$ & \\
\hline 事象1 & - & - & - & - & $C_{1}$ \\
\hline 事象2 & - & 0 & 0 & 0 & $C_{2}$ \\
\hline 事象3 & - & 0 & 0 & 0 & $C_{3}$ \\
\hline 事象4 & 0 & 0 & 0 & 0 & $C_{4}$ \\
\hline 事象5 & - & - & - & - & $C_{5}$ \\
\hline 事象6 & - & - & - & 0 & $C_{6}$ \\
\hline 事象7 & - & 0 & 0 & 0 & $C_{7}$ \\
\hline 事象8 & - & 0 & 0 & 0 & $C_{8}$ \\
\hline
\end{tabular}

※ : 各事象に対応する損失項目

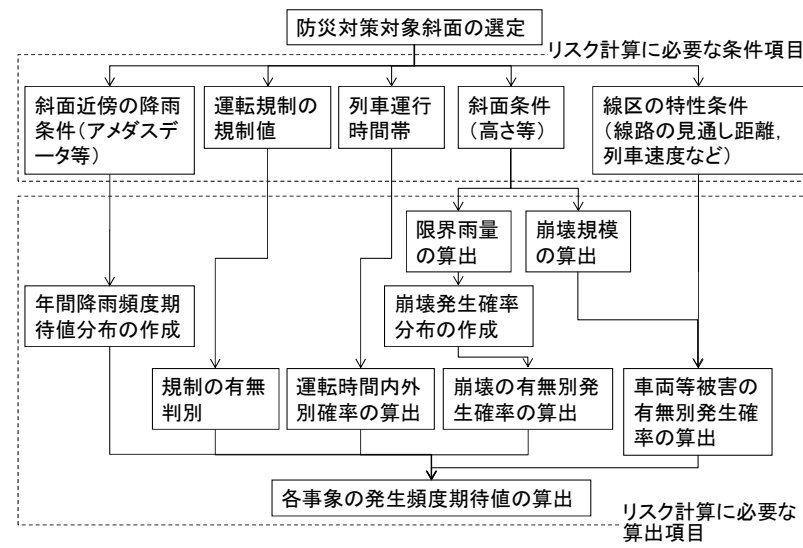

（a）各事象の発生頻度期待值の算出

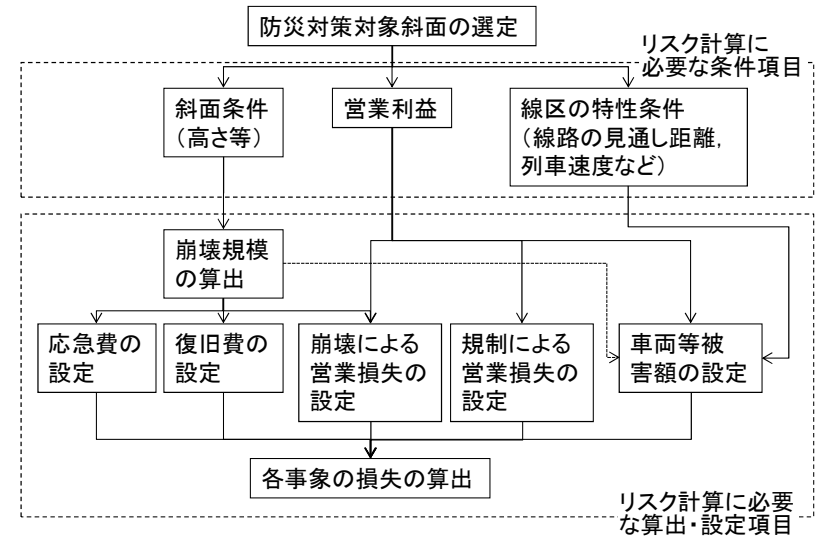

(b) 各事象の損失の算出

図-12 リスク計算の手順

\begin{tabular}{|c|c|c|c|c|c|c|c|c|c|c|c|c|}
\hline \multirow[b]{2}{*}{$\begin{array}{c}\text { 初期 } \\
\text { イベント } \\
n_{i} \\
\text { (回/年) }\end{array}$} & \multirow[b]{2}{*}{$\begin{array}{l}\text { 規制の有 } \\
\text { 無判別 }\end{array}$} & \multicolumn{4}{|c|}{ 各事象の発生確率 $p_{i}=p_{a i} \times p_{b i} \times p_{c i}$} & \multicolumn{4}{|c|}{ 損失項目 } & \multirow[b]{2}{*}{$\begin{array}{l}\text { 損失 } \\
\text { (円/回) } \\
\text { (合計) }\end{array}$} & \multirow[b]{2}{*}{$\begin{array}{c}\text { 各事象の } \\
\text { リスク } \\
\text { (円/年) }\end{array}$} & \multirow[b]{2}{*}{$\begin{array}{c}\text { 斜面の } \\
\text { 降雨時 } \\
\text { リスク } \\
\text { (円/年) }\end{array}$} \\
\hline & & $\begin{array}{l}\text { 崩壊の有 } \\
\text { 無別発生 } \\
\text { 確率 } p_{a i}\end{array}$ & $\begin{array}{l}\text { 運転時間内外 } \\
\text { 別確率 } p_{b i}\end{array}$ & $\begin{array}{l}\text { 車両等被 } \\
\text { 害の有無 } \\
\text { 別発生確 } \\
\text { 率 } p_{c i}\end{array}$ & $\begin{array}{l}\text { 各事象の } \\
\text { 発生頻度 } \\
\text { 期待値 } \\
(\text { 回/年) } \\
P_{i}\left(=p_{i} \times n_{i}\right)\end{array}$ & $\begin{array}{l}\text { 車両等 } \\
\text { 被害額 }\end{array}$ & 応急費 & 復旧費 & $\begin{array}{l}\text { 営業 } \\
\text { 損失 }\end{array}$ & & & \\
\hline 降雨 & 規制なし & 崩壊なし & & & \begin{tabular}{|l|}
$P_{1}$ \\
\end{tabular} & - & - & - & - & $C_{1}$ & $P_{1} \times C_{1}$ & \\
\hline & & 崩壊あり & 運転時間 外 & & $P_{2}$ & - & $\mathrm{O}$ & $\mathrm{O}$ & $\mathrm{O}$ & $C_{2}$ & $P_{2} \times C_{2}$ & \\
\hline & & & 運転時間 内 & 被害なし & $P_{3}$ & - & $\mathrm{O}$ & $\mathrm{O}$ & $\mathrm{O}$ & $C_{3}$ & $P_{3} \times C_{3}$ & \\
\hline & & & & 被害あり & $P_{4}$ & $\mathrm{O}$ & $\mathrm{O}$ & $\mathrm{O}$ & $\mathrm{O}$ & $C_{4}$ & $P_{4} \times C_{4}$ & $R_{\text {isk }}=$ \\
\hline & 規制あり & 崩壊なし & 運転時間 外 & & $P_{5}$ & - & - & - & - & $C_{5}$ & $P_{5} \times C_{5}$ & $\Sigma\left(P_{i} \times C_{i}\right)$ \\
\hline & & & 運転時間 内 & & $P_{6}$ & - & - & - & 0 & $C_{6}$ & $P_{6} \times C_{6}$ & \\
\hline & & 崩壊あり & 運転時間 外 & & $P_{7}$ & - & 0 & 0 & 0 & $C_{7}$ & $P_{7} \times C_{7}$ & \\
\hline & & & 運転時間 内 & & $P_{8}$ & - & 0 & 0 & 0 & $C_{8}$ & $P_{8} \times C_{8}$ & \\
\hline
\end{tabular}

図-13 リスク計算に必要な算出項目 


\section{(3) 計算事例}

\section{a) 計算条件}

実斜面でのリスク計算は上記(2)で示した方法で実行 するが，ここでは，計算事例を理解しやすいように，便 宜的に斜面の耐雨性（限界雨量）と降雨および運転規制 の規制值を表-3のように設定した．表に示寸とおり，他 の盛土と比較してC盛土の限界雨量は小さいが，A盛土 とB盛土は降雨が多い地域（ここでは，熊本のアメダス 地点データを利用）に，C盛土はこれよりも降雨が少な い地域（ここでは，東京のアメダス地点データを利用） に存在すると仮定した．また，規制值は熊本および東京 のアメダス地点データ（1976年〜2007年の32年間）をも とに時間雨量, 連続雨量それぞれの確率雨量を求め， A 盛土，C盛土は時間雨量，連続雨量とも約3年の確率雨 量を，B盛土は約2年の確率雨量とした．図-14に各盛土 の限界雨量曲線と規制值との関係を，アメダス観測所 「熊本」のデータを用いて作成した年間降雨頻度分布を 図-15に示寸．なお，アメダス観測所「東京」の年間降 雨頻度分布は図-11に示している.

運転時間内外別確率は，対象斜面付近の降雨出現時間 帯と関係があるが，本研究では計算を簡便にするために, 時間雨量 $r$ ，連続雨量Rのある降雨が24時間の中でどの時 間にも発生する可能性があるものと仮定したうえで，対 象斜面をとおる列車の1日における運転時間割合のみで 設定した．具体的には，運転時間内を 0.75 (1日のうち18 時間が運転時間），運転時間外を 0.25 とした。また，車 両等被害の有無別発生確率は，ここではリスクが大きく 計算される結果となるように, 被害ありを1, 被害なし を0とした.

計算事例における損失算出の考え方を表-4に，想定し た営業利益や崩壞土量とこの考え方に基づき設定した損
表-3 設定した斜面の耐雨性（限界雨量）と降雨（ア メダス地点）および運転規制の規制值

\begin{tabular}{|c|c|c|c|}
\hline 盛土名称 & A盛土 & B 盛土 & C盛土 \\
\hline 耐雨性 & 大 & 中 & 小 \\
\hline 限界雨量 & 18.5 & 17.0 & 14.5 \\
\hline 降雨 & 多 & 多 & 中 \\
\hline アメダス地点 & 熊本 & 熊本 & 東京 \\
\hline 規制値 & 大 & 中 & 小 \\
\hline 時間雨量 $(\mathrm{mm} / \mathrm{h})$ & 50 & 45 & 40 \\
\hline 連続雨量 $(\mathrm{mm})$ & 260 & 210 & 150 \\
\hline
\end{tabular}

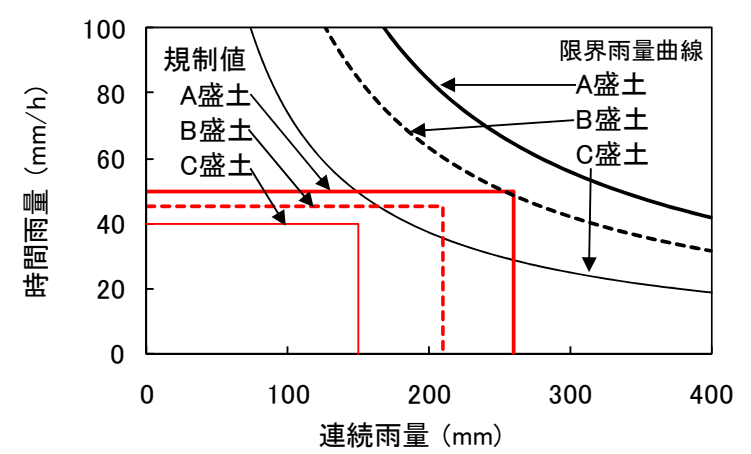

図-14限界雨量と運転規制の規制值との関係

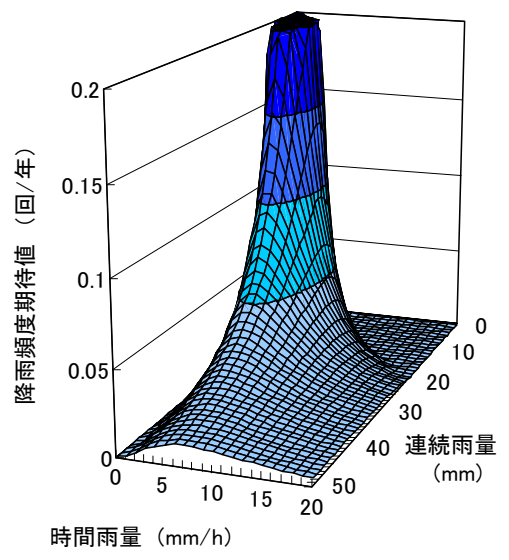

図-15 年間降雨頻度期待值分布 ${ }^{12)}$ (アメダス観測所「熊本」)

表-4 損失算出の考え方

\begin{tabular}{|c|c|}
\hline 応急費用 & 崩壊土量 $\times 10$ 万円 $/ \mathrm{m}^{3}$ \\
\hline 復旧費用 & 崩壊面積 $\times 1.5 \times 10$ 万円 $/ \mathrm{m}^{2}$ \\
\hline 応急時間 & 崩壊土量 $\times 0.2$ 時間 $/ \mathrm{m}^{3}$ \\
\hline 応急日数 & 応急時間/24を整数に繰り上げ \\
\hline 営業損失(a)（崩壊していないが規制をかけたた場合) & 営業利益 $\times 5$ 時間 $/(24 * 0.75)$ 時間 \\
\hline 営業損失(b)（営業時間外に崩壊した場合） & 営業利益 $\times$ 応急日数 \\
\hline 営業損失(c)（棠業時間内に崩壊した場合） & 営業利益 $\times($ 応急日数 +0.5$)$ \\
\hline
\end{tabular}

表-5 設定した損失

\begin{tabular}{|c|c|c|c|}
\hline 盛土名称 & A盛土 & B盛土 & C盛土 \\
\hline 営業利益(万円/日) & 450 & 200 & 45 \\
\hline 崩壊規模 & 小 & 中 & 大 \\
\hline 崩壊土量 $\left(\mathrm{m}^{3}\right)$ & 100 & 200 & 500 \\
\hline 崩壊面積 $\left(\mathrm{m}^{2}\right)$ & 200 & 270 & 330 \\
\hline 応急費用(万円) & 1000 & 2000 & 5000 \\
\hline 復旧費用(万円) & 3000 & 4050 & 4950 \\
\hline 営業損失(a)(万円) & 125 & 56 & 13 \\
\hline 営業損失(b)(万円) & 450 & 400 & 225 \\
\hline 営業損失(c)(万円) & 675 & 500 & 248 \\
\hline 車両等被害額 & \multicolumn{3}{|c|}{ 営業利益10日分, 30日分, 60日分 } \\
\hline
\end{tabular}


失を表-5に示す，また，車両等被害額については，営業 利益に比例すると仮定し, 営業利益の10日分, 30日分, 60日分を設定した.

\section{b) 現状のリスク算出結果}

車両等被害額を営業利益の30日分として上記で示した 条件から, 降雨時に想定される各事象の発生頻度期待值 とリスク，およびこれらリスクの合計值（斜面の降雨時 リスク）を算出した結果を，盛土ごとに表-6〜表-8に示 す。この表より, 降雨時リスクはB盛土が最も大きく, ついでC盛土，A盛土の順となることがわかる.

どの盛土においても運転が規制されたときに斜面崩壊 が発生する場合（以下，「規制あり，崩壊あり」とい う）の事象7，事象8のリスクが他と比較して大きい結果 となっている. この理由について以下に考察する.

斜面の降雨時リスクに大きな影響を及ぼす事象は，運 転が規制されずに斜面崩壊が発生し，これにより車両等 に被害が生じる場合（以下，「車両等被害あり」とい う）の事象4，運転を規制したが斜面は崩壊しない場合 （以下，「規制あり，崩壊なし」という）の事象6，お よび「規制あり，崩壊あり」の事象7，事象8である。こ れらの事象ごとに発生頻度期待值と損失の相対的な大小 関係を示すと表-9となる。

一般的に，降雨時運転規制の規制值は斜面が崩壊する 恐れが高まる雨量よりも小さい值が設定される．降雨頻 度は雨量が小さいほど大きいことから，「規制あり，崩 壊なし」の発生頻度期待值は相対的に大きく, ついで 「規制あり，崩壊あり」となる、「車両等被害あり」の 発生頻度期待值は，規制值以下の降雨で発生するため比 較的降雨頻度は大きいがこの降雨量では斜面が崩壊する 確率が小さいため，相対的に小さくなる．一方，損失は 発生頻度期待值とは反対の傾向となり，斜面が崩壊した 場合の損失と車両等に生じる被害の合計值で計算される

「車両等被害あり」の損失が相対的に大きく, ついで 「規制あり，崩壊あり」となる。「規制あり，崩壊な し」の損失は運転を規制したことによる営業損失のみで あるため，相対的に小さくなる.

したがって，実際の計算においては，表-91示した相 対的な大小関係が絶対值として大きく乘離している場合 は，表に示した事象のいずれかの事象が斜面の降雨時リ スクに大きな影響を及ぼすことになる．本計算事例では, 「車両等被害あり」の発生頻度期待值が「規制あり, 崩 壊あり」と比較して明らかに小さく，また，「規制あり， 崩壊なし」の損失（表-5の営業損失(a)）が「規制あり, 崩壊あり」の損失（表-5の応急費, 復旧費, および営業 損失(b)または営業損失(c)を足した值) よりも明らかに小 さい.このため，「規制あり，崩壊あり」のリスクが他 の事象と比較して大きく, 計算事例ではこの事象のリス クに斜面の降雨時リスクが依存する結果となった.
表-6 現状のリスク計算結果（A盛土）

\begin{tabular}{|c|c|c|c|}
\hline 事象 & $\begin{array}{c}\text { 事象ごとの } \\
\text { 年間発生頻度 } \\
\text { 期待值 (回/年) }\end{array}$ & \begin{tabular}{|c|} 
事象ごとの \\
リスク \\
(万円/年) \\
\end{tabular} & $\begin{array}{l}\text { リスク合計 } \\
\text { (万円/年) }\end{array}$ \\
\hline 事象1 & \begin{tabular}{|l|}
77.785 \\
\end{tabular} & \begin{tabular}{l|}
0 \\
\end{tabular} & \multirow{8}{*}{1677} \\
\hline 事象2 & 0.002 & 7 & \\
\hline 事象3 & 0.000 & 0 & \\
\hline 事象4 & 0.005 & 88 & \\
\hline 事象5 & 0.152 & 0 & \\
\hline 事象6 & 0.455 & 57 & \\
\hline 事象7 & 0.083 & 367 & \\
\hline 事象8 & 0.248 & 1158 & \\
\hline
\end{tabular}

表-7 現状のリスク計算結果（B盛土）

\begin{tabular}{|c|c|c|c|}
\hline 事象 & $\begin{array}{c}\text { 事象ごとの } \\
\text { 年間発生頻度 } \\
\text { 期待值(回/年) }\end{array}$ & $\begin{array}{c}\text { 事象ごとの } \\
\text { リスク } \\
\text { (万円/年) }\end{array}$ & $\begin{array}{c}\text { リスク合計 } \\
\text { (万円/年) }\end{array}$ \\
\hline 事象1 & 77.412 & 0 & \multirow{2}{*}{} \\
\hline 事象2 & 0.002 & 16 & \multirow{2}{*}{3383} \\
\hline 事象3 & 0.000 & 0 & \multirow{2}{*}{} \\
\hline 事象4 & 0.007 & 93 & \\
\hline 事象5 & 0.203 & 0 & \\
\hline 事象6 & 0.608 & 34 & \\
\hline 事象7 & 0.124 & 801 & \\
\hline 事象8 & 0.372 & 2440 & \\
\cline { 1 - 2 }
\end{tabular}

表-8＼cjkstart現状のリスク計算結果（C盛土）

\begin{tabular}{|c|c|c|c|}
\hline 事象 & $\begin{array}{c}\text { 事象ごとの } \\
\text { 年間発生頻度 } \\
\text { 期待値(回/年) }\end{array}$ & $\begin{array}{c}\text { 事象ごとのク } \\
\text { リスク } \\
\text { (万円年) }\end{array}$ & $\begin{array}{c}\text { リスク合計 } \\
\text { (万円/年) }\end{array}$ \\
\hline 事象1 & 69.101 & 0 & \multirow{2}{*}{} \\
\hline 事象2 & 0.002 & 25 & \multirow{2}{*}{2219} \\
\hline 事象3 & 0.000 & 0 & \\
\hline 事象4 & 0.007 & 84 & \\
\hline 事象5 & 0.179 & 0 & \\
\hline 事象6 & 0.538 & 7 & \\
\hline 事象7 & 0.052 & 525 & \\
\hline 事象8 & 0.155 & 1578 & \\
\cline { 1 - 2 }
\end{tabular}

表-9 降雨時事象の発生頻度期待值と損失の相対的な 大小関係

\begin{tabular}{|c|c|c|}
\hline 降雨時の事象 & $\begin{array}{c}\text { 発生頻度 } \\
\text { 期待値 }\end{array}$ & 損失 \\
\hline $\begin{array}{c}\text { 「車両等被害あり } \\
\text { (事象4) }\end{array}$ & 小 & 大 \\
\hline $\begin{array}{c}\text { 「規制あり, 崩壊なし」 } \\
\text { (事象6) }\end{array}$ & 大 & 小 \\
\hline $\begin{array}{c}\text { 「規制あり, 崩壊あり」 } \\
\text { (事象7, 8) }\end{array}$ & 中 & 中 \\
\hline
\end{tabular}

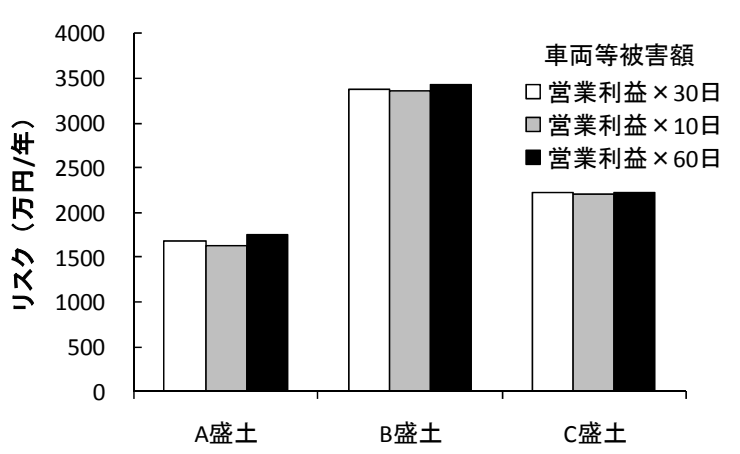

図-16 現状のリスクの比較 
以上により，B盛土では「規制あり，崩壊あり」の事 象の発生頻度期待值 (事象7，8の合計值）が他の盛土と 比較して最も大きく，崩壊規模はA盛土より大きく，C 盛土より小さく設定しているため，B盛土のリスクが大 きい結果になったといえる.

図-16に車両等被害額を営業利益の10日分，30日分， 60日分として算出した降雨時リスクを盛土ごとに比較し た結果を示す。この図より，本計算事例で設定した範囲 では，車両等被害額の設定が異なっても各盛土の降雨時 リスクに大きな差はないことがわかる。これは，前述し たとおり，「車両等被害あり」の発生頻度期待值が「規 制あり，崩壊あり」と比較して明らかに小さいためであ る. 本計算事例では上記のような結果になったが，「車 両等被害あり」の事象は重大な事故に繋がる可能性があ ることから，この事象のリスクのみではなく発生頻度期 待值も斜面同士で比較することにより，重大な事故が発 生する可能性の高い斜面を抽出することが重要であると 考える.

このように，表-3，表-5に示した条件のみでは防災対 策の順位を判断することは困難であるが，図-16に示し たような降雨時リスクの算出結果は，対策の順位を決定 する際に参考になると考える.

\section{c) 対策後のリスク算出結果}

崩壊の危険度が高い盛土や切土に対してハード対策を 実施する場合，盛土や切土は鉄道事業者の管理用地内で あるため, 崩壊を生じさせないようにのり面防護工など の発生源対策を講じることが基本となる. そこで，上記 a),b)で示した盛土にのり面防護工として図-17に示すよ うなプレキャスト格子枠工を施工した場合のリスク（以 下，対策後のリスクという）を算出し，現状のリスクと 比較することで対策の効果を定量化することを試みる.

対策後のリスクを算出するために必要な条件を表-10 に示す．対策後の事象ごとの年間発生頻度期待值を算出 する条件は，上記b)で示した現状の条件のうち，限界雨 量の值のみ異なる. 盛土にのり面防護工を施工した場合 は, 限界雨量が増加し, 図-5の限界雨量曲線の例に示し たとおり無防護と比較して右上に限界雨量曲線が描かれ る，すなわち，耐雨性が向上する，ここで，八ード対策 としてプレキャスト格子枠工を施工しても耐雨性が無限 大となるのではなく，表-1に示した効果点のみ耐雨性が 向上するものとした。 したがって，防護工施工後の限界 雨量を超える降雨があれば崩壊することになる.

事前対策費（プレキャスト格子枠工の施工費）につい ては，表-4に示した復旧費の算出の考え方に準じ，崩壊 面積の2倍の範囲対策を行うものと仮定して算出した. 対策後の盛土が崩壊したときの応急費は，現状よりも対 策工を除去する分だけ多くかかると想定して現状の応急 費の1.5倍とし，復旧費は事前対策費と同じだけかかる
表-10 対策後のリスク計算の条件

\begin{tabular}{|c|c|c|c|}
\hline 盛土名称 & A盛土 & B盛土 & C盛土 \\
\hline 防護工の効果点 & \multicolumn{3}{|c|}{4.26} \\
\hline 限界雨量 & 22.76 & 21.26 & 18.76 \\
\hline 事前対策費用 $($ 万円 $)$ & 4000 & 5400 & 6600 \\
\hline 応急費用 $($ 万円 $)$ & 1500 & 3000 & 7500 \\
\hline 復旧費用 $($ 万円 $)$ & 4000 & 5400 & 6600 \\
\hline
\end{tabular}

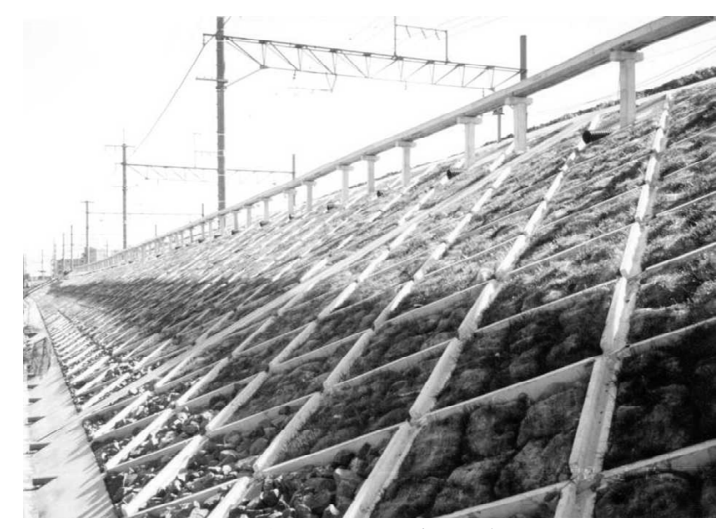

図-17 プレキャスト格子枠工の例

表-11 対策後のリスク計算結果（A盛土）

\begin{tabular}{|c|c|c|c|}
\hline 事象 & $\begin{array}{c}\text { 事象ごとの } \\
\text { 年間発生頻度 } \\
\text { 期待值 (回/年) }\end{array}$ & $\begin{array}{l}\text { 事象ごとの } \\
\text { リスク } \\
\text { (万円/年) }\end{array}$ & $\begin{array}{l}\text { リスク合計 } \\
\text { (万円/年) }\end{array}$ \\
\hline 事象1 & 77.792 & 0 & \multirow{8}{*}{617} \\
\hline 事象2 & 0.000 & 0 & \\
\hline 事象3 & 0.000 & 0 & \\
\hline 事象4 & 0.000 & 0 & \\
\hline 事象5 & 0.212 & 0 & \\
\hline 事象6 & 0.637 & 80 & \\
\hline 事象7 & 0.022 & 131 & \\
\hline 事象8 & 0.066 & 407 & \\
\hline
\end{tabular}

表-12 対策後のリスク計算結果（B盛土）

\begin{tabular}{|c|c|c|c|}
\hline 事象 & $\begin{array}{c}\text { 事象ごとの } \\
\text { 年間発生頻度 } \\
\text { 期待値 (回/年) }\end{array}$ & $\begin{array}{c}\text { 事象ごとの } \\
\text { リスク } \\
\text { (万円/年) }\end{array}$ & $\begin{array}{l}\text { リスク合計 } \\
\text { (万円/年) }\end{array}$ \\
\hline 事象1 & 77.422 & 0 & \multirow{8}{*}{1362} \\
\hline 事象2 & 0.000 & 0 & \\
\hline 事象3 & 0.000 & 0 & \\
\hline 事象4 & 0.000 & 0 & \\
\hline 事象5 & 0.290 & 0 & \\
\hline 事象6 & 0.869 & 48 & \\
\hline 事象7 & 0.037 & 326 & \\
\hline 事象8 & 0.111 & 988 & \\
\hline
\end{tabular}

表-13 対策後のリスク計算結果（C盛土）

\begin{tabular}{|c|c|c|c|}
\hline 事象 & $\begin{array}{c}\text { 事象ごとの } \\
\text { 年間発生頻度 } \\
\text { 期待値 (回/年) }\end{array}$ & $\begin{array}{c}\text { 事象ごとの } \\
\text { リスク } \\
\text { (万円/年) }\end{array}$ & $\begin{array}{l}\text { リスク合計 } \\
\text { (万円/年) }\end{array}$ \\
\hline 事象1 & 69.110 & 0 & \multirow{8}{*}{322} \\
\hline 事象2 & 0.000 & 0 & \\
\hline 事象3 & 0.000 & 0 & \\
\hline 事象4 & 0.000 & 0 & \\
\hline 事象5 & 0.225 & 0 & \\
\hline 事象 6 & 0.676 & 8 & \\
\hline 事象7 & 0.005 & 78 & \\
\hline 事象8 & 0.016 & 235 & \\
\hline
\end{tabular}


ものと想定して設定した．その他の損失条件は上記b)現 状のリスクと同じとした.

車両等被害額を営業利益の30日分として上記で示した 条件から, 降雨時に想定される各事象の発生頻度期待值 とリスク，およびこれらリスクの合計值（斜面の降雨時 リスク）を算出した結果を，盛土ごとに表-11〜表-13に 示す．現状のリスクを算出した表-6〜表-8と比較すると,

「規制あり，崩壊あり」の事象7，8の発生確率およびリ スクが減少していることから，リスクの合計值も（斜面 の降雨時リスク）大きく減少する結果となることがわか る. なお，表-11〜表-13より「車両等被害あり」の事象 4の発生確率がほぼ0であることから，車両等被害額を変 更しても対策後のリスクはほぼ同じ結果となった。 上記 のような計算結果になった理由は，のり面防護工を施工 することにより限界雨量が増加し, 連続雨量 $R$, 時間雨 量 $r$ 対応寸る斜面崩壊確率が対策前（現状）と比較し て大きく減少したためである。

車両等被害額を営業利益の30日分として算出した現状 のリスク $R_{\mathrm{ikk}}$ と対策後のリスク $R_{\text {isk }}^{\prime}$ およびリスクの低減量 $\Delta R_{\text {ik }}\left(=R_{\text {isk }}-R_{\text {isk }}^{\prime}\right)$ を図-18に示す．さらに，リスクが経 年とともに累積されるものとし, 図-19に示寸とおり, 現状および対策後の累積リスクを算出した．対策後の累 積リスクは事前対策費を損失と考え初期值に加算した. そして，図に示寸とおり，現状よりも対策後の累積リス クが下回ることになる年数を投資効果発生年数 $T$ と定義 し, リスク低減量以外に対策の効果を把握する指標とし た. 投資効果発生年数 $T$ は事前対策費Wをリスク低減量 $\Delta R_{\text {ik }}$ で除す（ $\left.T=W / \Delta R_{\text {ik }}\right)$ ことにより求められ，算出結 果を表-14に示した. 投資効果発生年数 $T$ は，上記式より 事前対策費に対してリスク低減量が大きい，つまり対策 の効果が高いほど小さくなる.

図-18よりどの盛土に対してものり面防護工を講じる ことでリスクを大きく低減できること，表-14より投資 効果発生年数も 2.7 年 3.8年と比較的小さいことから, 対策の効果が高いことがわかる．このように，表-10の みではのり面防護工による対策の効果を把握することは 困難であるが，図-18，表-14に示したように現状のリス クと対策後のリスクを比較することで，対策の効果を定 量的に把握することが可能となる。この結果は，のり面 防護工による対策を実施すべきかどうかの定量的な判断 の際に参考になると考える，なお，投資効果発生年数は 事前対策費とリスク低減量に依存し，リスク低減量が大 きい場合には事前対策費が明らかに大きくても投資効果 発生年数が小さくなることが想定される. したがって, 上記に示したリスク低減量と投資効果発生年数に加えて, 鉄道事業者が防災投資に割り当てられる年間予算に占め る事前対策費の割合も含めて総合的に対策効果を判断す る必要がある.

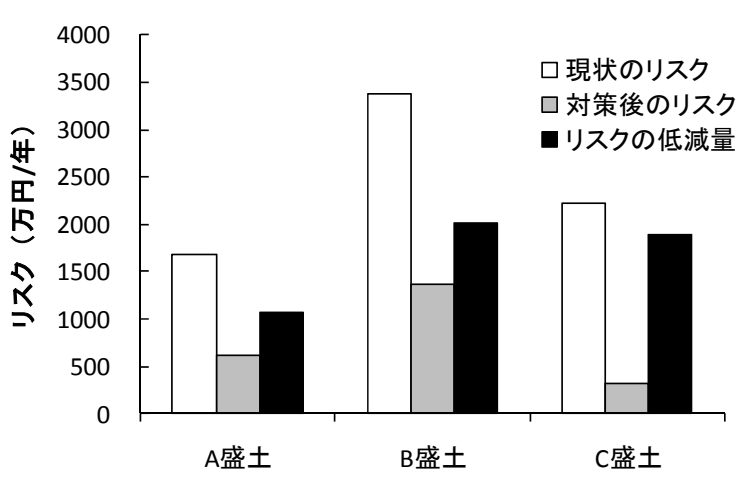

図-18＼cjkstart現状と対策後のリスクおよびリスクの低減量

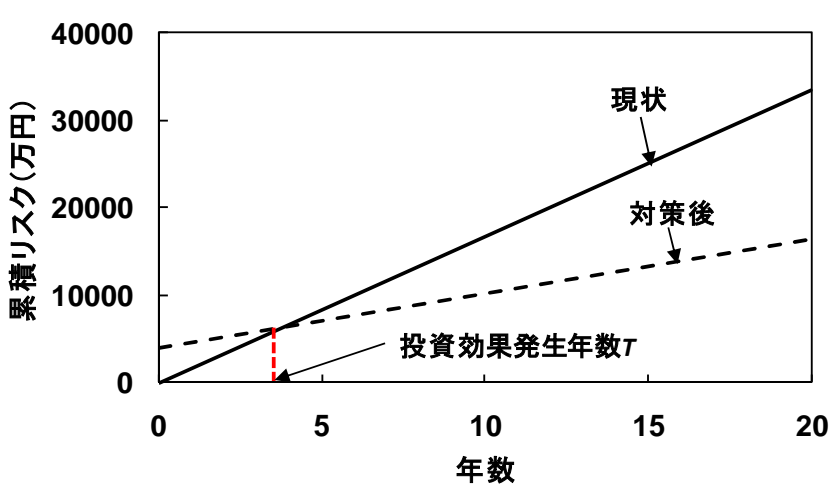

図-19 現状と対策後の累積リスク

表-14 投資効果発生年数の計算結果

\begin{tabular}{|c|c|c|c|}
\hline 盛土名称 & A盛土 & B盛土 & C盛土 \\
\hline 投資効果発生年数 $($ 年) & 3.8 & 2.7 & 3.5 \\
\hline
\end{tabular}

\section{d）防災対策の意思決定方法}

計算事例を踏まえて，リスク算出結果を利用して防災 対策の意思を決定するフローを図-20に示す．このフロ 一では，まず，定期的な検查等により抽出された防災対 策対象斜面の現状のリスクを算出する. そして，必要に より，「車両等被害あり」の事象4の発生頻度期待值を 斜面同士で相対的に比較する.これは，この事象が重大 な事故に繋がる可能性があるためであり，この事象の発 生頻度期待值が大きい斜面を抽出することは特に重要で あると考え，フローに記載した。 この事象の発生頻度期 待值が大きい斜面については，まず，降雨時運転規制の 規制值を減少させ，規制を強化させることが必要である と考える.

次に，現状のリスクを斜面同士で相対的に比較し，リ スクの小さい斜面は防災対策の順位が低く, リスクの大 きい斜面は順位が高いものと判断寸る. 寸わわち, リス クの大きい順に対策の優先順位が高いものとし, 優先順 位が高い斜面には防災対策を講じることになる.

防災対策が必要と判断された斜面については，のり面 防護工による対策後のリスクを算出する．これは，前述 
したとおり，崩壊の危険度が高い盛土や切土に対してハ 一ド対策を実施する場合, 盛土や切土は鉄道事業者の管 理用地内であるため, 崩壊を生じさせないようにのり面 防護工などの発生源対策を講じることが基本となるため である．したがって，対策後のリスクと現状のリスクと から, リスクの低減量や投資効果発生年数を求め, これ らの值を斜面同士で相対的に比較し，対策の効果が大き い斜面はのり面防護工による対策を講じるものと判断す る. なお，斜面の耐雨性が向上したことでさらなる列車 の安定輸送を確保できる可能性があるため, 必要により 降雨時運転規制值を増加させ，規制を緩和させることも 検討する.

ここで，のり面防護工による対策の効果が小さい場合 について考察する. 上記b), c)で示した計算事例より, 現状のリスク計算結果である表-6〜表-8とのり面防護工 の対策後のリスク計算結果である表-11〜表-13とを比較 すると，どの盛土においても「車両等被害あり」の事象 4と「規制あり，崩壊あり」の事象7，事象8はリスクが 低減しているのに対して，「規制あり，崩壊なし」の事 象6のリスクは増加していることがわかる．したがって， リスク全体に対してこの事象のリスクの割合が大きいと きは，のり面防護工による対策の効果が小さいことが想 定される．また，上記c)で述べたとおり，対策の効果を 現寸指標である投資効果発生年数は，事前対策費用に依 存する值であるため，対策対象斜面の範囲が膨大な場合 には，対策によるリスクの低減量に対して事前対策費用 が明らかに大きくなり，のり面防護工による対策の効果 が小さいと判断される.
このため，現状および対策後のリスク算出結果におい て，リスク全体に対して「規制あり，崩壊なし」の事象 6のリスクの割合が大きい場合は，降雨時運転規制の規 制值を増加させ，規制を緩和することを講じるものと判 断する. また，この場合以外は，対策によるリスクの低 減量に対して事前対策費用が明らかに大きいことが想定 されることから，のり面防護工以外の工法によるハード 対策として, 土砂止擁壁による線路際対策（切土斜面の 場合）など，または降雨時運転規制の規制值を減少させ， 規制を強化することを講じるものと判断する.

上記で示したとおり，こうしたフローに沿ってリスク 算出結果を利用寸ることで，これまで斜面の健全度や線 区の重要度などから経験的に決定していた防災対策の意 思を定量的に決定することが可能であると考える.

\section{7. 結論}

本研究では, 降雨時に想定される事象の発生頻度期待 值と損失から鉄道沿線斜面の崩壊危険度を降雨時リスク として算出する方法, および計算事例をもとにリスク算 出結果を利用した防災対策の意思決定方法を検討した. この結果, 以下のような結論を得た。

1) 斜面の崩壊発生確率分布と斜面近傍の年間降雨頻度 期待值分布などから降雨時に想定される事象の発生 頻度期待值を求め, これと上記事象が発生したとき の損失とから, 式(1), 式(2)より鉄道沿線斜面の降雨 時リスクを算出する方法を提案した.

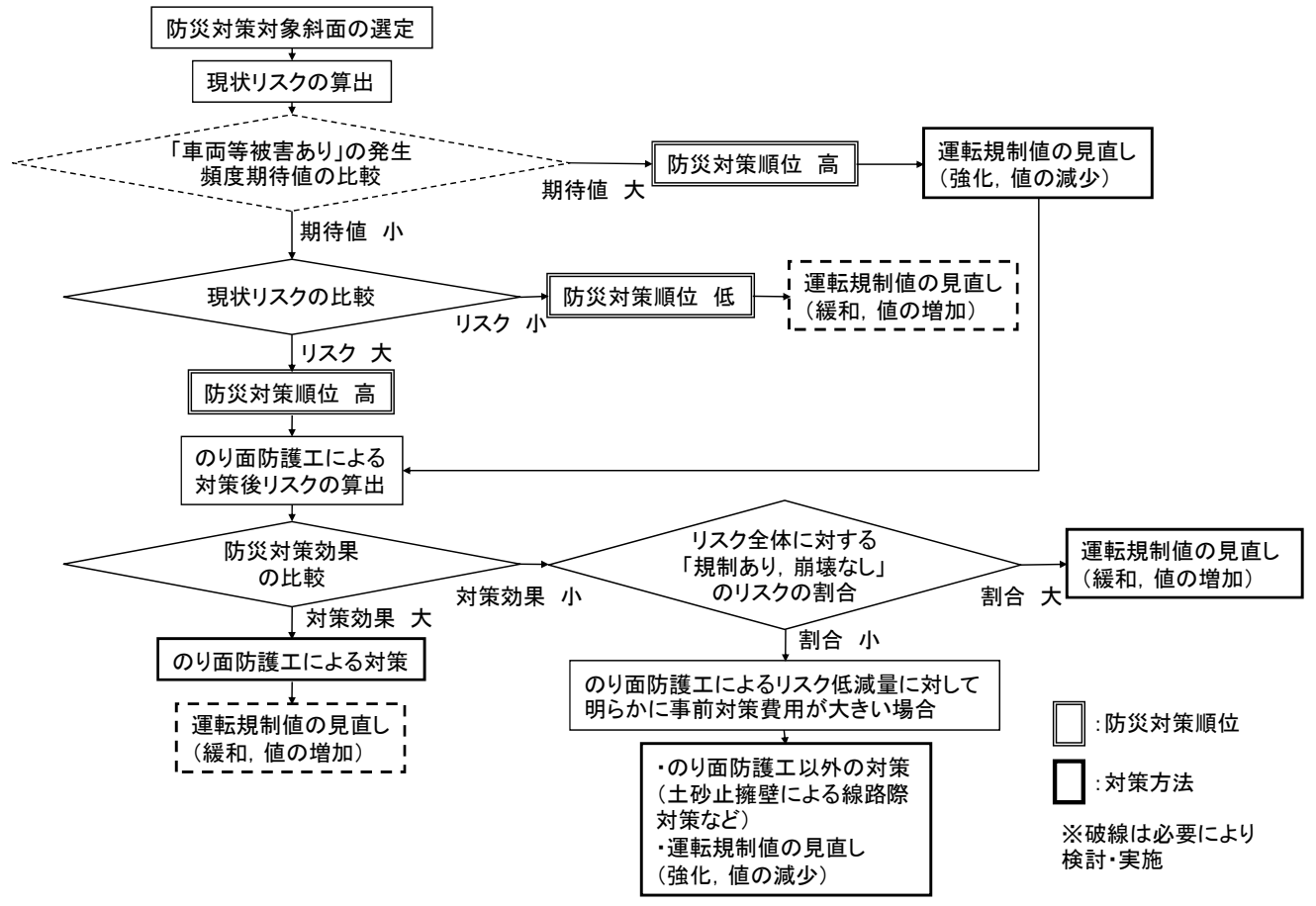

図-20 リスク算出結果を利用した防災対策の意思決定フロー 
2）防災対策対象斜面の現状の降雨時リスクを求め，こ のリスクを斜面同士相対的に比較することで，対策 の順位を決定する際に参考となることを計算事例に より示唆した.

3）防災対策としてのり面防護工を施工した場合のリス クを算出し，現状のリスクと比較してリスクの低減 量や投資効果発生年数を求めることで，対策の効果 を定量的に把握してののり面防護工の実施の可否を 判断する際の参考となることを計算事例により示唆 した.

4) これまで斜面の健全度や線区の重要度などから経験 的に決定していた防災対策の意思を，計算事例を踏 まえて, リスク算出結果を利用して定量的に決定す ることを可能とするフローを提案した.

上記で示した方法に必要なデータは，簡易な調査によ り得られる盛土や切土の各種条件と斜面近傍のアメダス データなどであり，これらは容易に入手できる．したが って, 鉄道沿線に崩壊の危険性が高い斜面が数多く存在 する場合に，本研究の成果は適用できると考える

本研究では，降雨により崩壊する可能性がある斜面を 対象として防災対策の意思を決定する方法について述心 たが，鉄道沿線では落石などの災害も発生する．したが って, 鉄道沿線で発生する災害に対して防災対策を効果 的・効率的に実施するためには, 落石災害の危険度をリ スクとして評価する方法も検討する必要があると考える.

謝辞 : 本研究を進めるにあたっては, (財)深田地質研究 所の亀村勝美氏，大成建設(株)の堀倫裕氏，国士舘大学 の岡田勝也教授より多くのご教示を頂いた. ここに深く 謝意を表します。

\section{参考文献}

1) 大津宏康, 大西有三，水守守：高速道路に近接寸る 斜面を対象とした自然災害に対するリスクマネジメ ント手法に関寸る提案, 土木学会論文集, No.658/VI48, pp. $245-254,2000.9$

2) 榎明潔：降雨時の斜面表層崩壊，土と基䃈，Vol.47, No.5, pp.17-20, 1999.
3) 大津宏康，大西有三，高橋健二， Srisin Janrungautai : 貯留型タンクモデル法による地下水挙動を考慮した 斜面リスク評価に関する研究, 土木学会第 58 回年次 学術講演会, IV-346, pp.691-692, 2003.

4) 沖村孝, 鳥居宣之, 萩原貞宏, 吉田正樹 : リスクマ ネジメント理論を用いた道路のり面の危険度評価手 法に関する研究, 建設工学研究所論文報告集, 第 43A 号, pp.51-64, 2001.11

5) 沖村孝 : 山腹表層崩壊発生位置の予知に関する一研 究, 土木学会論文集, No.331, pp.113-120, 1983.

6) 沖村孝, 市川龍平 : 数值地形モデルを用いた表層崩 壊危険度の予測法, 土木学会論文集, No.358/III-3, pp.69-75, 1985.

7) 田中衛, 恒岡伸幸, 三木博史 : 道路斜面災害のリス ク評価法について，土木技術資料，44-12，pp.50-55， 2002.

8) 岡田勝也, 杉山友康, 村石尚, 野口達雄 : 統計的手 法による鉄道盛土の降雨災害危険度の評価手法，土 木学会論文集，No.448/III-19，pp.25-34， 1992.

9) Okada, K., Sugiyama, T., Muraishi, H., Noguchi, T. and Samizo, M.: Statistical risk estimating method for rainfall on surface collapse of a cut slope, Soils and Foundations, Vol.34, No.3, pp.49-58, 1994.

10) Sugiyama, T., Okada, K., Muraishi, H., Noguchi, T. and Samizo, M.: Statistical rainfall risk estimating method for a deep collapse of a cut slope, Soils and Foundations, Vol.35, No.4, pp.37-48, 1995.

11) 杉山友康, 岡田勝也, 秋山保行, 村石尚, 奈良利 孝：鉄道盛土の限界雨量に及ぼす防護工の効果，土 木学会論文集, No.644/IV-46, pp.161-171， 2000.

12) 布川修, 杉山友康, 太田直之, 畑明仁, 堀倫裕, 亀 村勝美，岡田勝也：鉄道の降雨時運転規制を考慮し た斜面崩壊の発生頻度期待值算出方法, 土木学会論 文集 C，Vol.66，No.1，pp.78-88，2010.

13) 村上温, 野口達雄監修: 鉄道土木構造物の維持管理, pp.672, 日本鉄道施設協会, 1998.

14) Benjamin, J. R. and Cornell, A. A. : Probability, Statistics and Decision for Civil Engineers, McGraw-Hill, pp.578580, 1970.

15) 布川修, 杉山友康, 森泰樹, 太田直之, 岡田勝也： 統計的手法による鉄道盛土と切土の降雨による崩壊 土量の概略予測手法, 土木学会論文集 C, Vol.65, No.3, pp.728-744, 2009.

(2010. 6. 22 受付) 


\section{A METHOD TO DETERMINE THE PRIORITY OF INVESTMENT IN DISASTER PREVENTION FOR RAINFALL-INDUCED SLOPE FAILURE}

\section{Osamu NUNOKAWA, Tomoyasu SUGIYAMA, Taiki MORI and Akihito HATA}

Slope failure resulting from heavy rainfall on rail road lines is a common occurrence, making it essential to minimize the phenomenon in the interests of maintaining safe, punctual train operation. It is also necessary to evaluate disaster risk of individual slopes by considering the probability and potential cost of rainfall-related slope failure. We developed a method to evaluate disaster risk for slope failure using a risk estimation technique. This paper describes this developed method, and the method of priority determination for investment to prevent slope failure caused by intense rainfall using this developed technique. 